\title{
Ethical considerations of the perinatal necropsy
}

\author{
T Y Khong Department of Pathology, Women's and Children's Hospital, North Adelaide, Australia
}

\begin{abstract}
The perinatal necropsy is an important investigation following fetal or neonatal loss. Legal requirements on registration decree that consent is needed before necropsy can proceed in some of these babies. However, there are ill-defined grey areas which are open to legal and ethical difficulties. This paper discusses the problems that can arise with consent for a necropsy in the perinatal period. Some of these problems are clearly legal or ethical but all can cause distress to parents at a time of grief and bereavement. The issues may not be readily resolved but public debate and ad hominem decisions on each perinatal loss may help to alleviate the problems.
\end{abstract}

\section{Introduction}

The necropsy of babies dying in the perinatal and neonatal periods is of practical importance to the families of the dead babies and to the clinicians involved in their care. Clinically relevant information that may alter genetic or obstetrical counselling is found in as many as 46 per cent of cases following a perinatal postmortem examination. ${ }^{1-3}$ The perinatal necropsy appears to have been relatively immune to the considerable fall in necropsy rates affecting adult hospital patients over the last 40 years, attributable to, among other many and complex factors, consent for necropsy. ${ }^{4-6}$ With the onus on doctors to provide informed counselling at all levels of patient interaction, it is opportune to consider some of the ethical issues related to the perinatal necropsy consent.

\section{On whom should consent be sought?}

The World Health Organisation (WHO) recommends that national statistics should include all fetuses and infants of at least $500 \mathrm{~g}$ birthweight or, when birthweight is unavailable, the corresponding gestational age (22 weeks) or body length $(25 \mathrm{~cm}$ crown-heel), whether dead or alive. Perinatal deaths include also neonatal deaths occurring within the first seven days of life as recommended by the WHO

\section{Key words}

Necropsy; perinatal; consent; postmortem examination. for international comparison. ${ }^{7}$ These definitions are for statistical purposes only and definitions may vary for national registration purposes. In South Australia, infants of at least $400 \mathrm{~g}$ birthweight or 20 weeks' gestation are included ${ }^{8}$ while the lower limit in other countries can be 13 (Japan), 16 (Norway), or 24 (United Kingdom) weeks' gestation. ${ }^{9} 10$

In many countries, consent is required for necropsy on registrable losses. ${ }^{11}$ Thus, in our state, intrauterine losses delivered after 20 weeks' gestation, whatever the birthweight, would require consent and this includes the macerated fetus which is delivered weeks after demise - the so-called missed abortions. There are, however, grey areas. What is the legal view when, for example, during the examination of a placenta from a term pregnancy, the pathologist is confronted with an unsuspected co-twin that had clearly died in the early stages of pregnancy - the fetus papyraceous or fetus compressus? Its size may be that of an eight-week fetus but its gestational age may be 40 weeks. With advances in reproductive medicine, this question is likely to be raised increasingly. Elective fetal reduction, to reduce quadruplet to triplet or twin pregnancies or from triplet to twin or singleton pregnancies, is performed in multiple pregnancies resulting from assisted conceptions to optimise obstetrical and neonatal outcome: this will result in an iatrogenic fetus papyraceous. A not dissimilar problem may arise in a twin pregnancy spontaneously miscarried at 19 weeks in which one twin is more than $400 \mathrm{~g}$ while the other is less than $400 \mathrm{~g}$; this could result from idiopathic intrauterine growth retardation of one twin or from twin-to-twin transfusion syndrome, a condition where the circulations of both twins are enjoined through the placenta but direction of blood-flow favours the growth and development of one co-twin at the expense of the other. In this example, one twin does not need to be registered while the other must be. Should one twin be autopsied without need for consent while consent is sought for the other?

Because of increasing public awareness of the fetus as an entity, ${ }^{12}{ }^{13}$ obstetricians may seek formal consent for necropsy on non-registrable intrauterine losses although this is not legally required. What 
impact this will have is unclear but our experience has shown that refusals for necropsy are not infrequent among these non-registrable mid-trimester miscarriages where consent has been sought. On the other hand, while seeking of consent for necropsy of non-registrable fetal losses may be more sensitive to the parents' feelings, as the Lancet asked, when is a fetus a dead baby? ${ }^{\text {12 }}$

Another area where there is potential for hurt is in termination of pregnancy following antenatal diagnosis. Consent for this may be overlooked when it is assumed that the non-registrable fetus will automatically be autopsied; however, this may transgress the wishes of the parents. Since terminations of pregnancies are being performed at earlier gestations following antenatal diagnosis, this may prove to be an increasing area of difficulty and, ideally, a necropsy should be discussed as part of antenatal diagnosis counselling.

Implicit in granting consent for treatment or invasive procedures is pathological examination of tissue procured from such procedures, for example microscopical examination of the appendix following an appendicectomy. Should consent be sought, however, for pathological examination of the placenta that is delivered normally after a natural event? After all, whether a necropsy is performed or not, the placenta is an invaluable part of the investigation following perinatal loss. ${ }^{14}$ There is a notion that the fetus has a special status arising from its potential for developing into a fully formed human being but the placenta is undeserving of such special status. ${ }^{15}$ This ignores the sensitivities of some cultural groups which attach as much importance to the placenta as to the fetus ${ }^{16}$ and parents may, and have been known to, refuse examination of the placenta. With multiculturalism being commonplace in many countries, this is an important consideration even with regard to the placenta in which there has not been a perinatal loss.

\section{Who should seek consent?}

The ability of the person seeking consent for necropsy in getting it has been raised in relation to the adult necropsy. ${ }^{17}$ No studies have yet addressed this issue in perinatal necropsy, perhaps because of the higher necropsy rate in the perinatal population. ${ }^{18}$ However, it is imperative that counselling for necropsy consent should be informed. ${ }^{19}$ The possible genetic counselling ramifications of failure to necropsy a fetus or neonate may not be made clear if the junior staff member or lay administrator seeks consent. The recurrence risks following an apparently isolated neural-tube defect or spina bifida, for example, may be significantly different if there are additional abnormalities. ${ }^{20}$ Clearly, there are implications for litigation if necropsy had been declined when counselling for necropsy consent was less than comprehensive. Accordingly, I believe that the most senior medical practitioner involved in the care of $\frac{\text { TI }}{\vec{F}}$ the parents should seek consent. A role for the pathologist in the post-necropsy conference has been advocated ${ }^{21}$ and it is possible that there may be a role $\stackrel{\vec{s}}{\overrightarrow{2}}$ for the perinatal pathologist in the pre-necropsy음 conference and counselling for necropsy consent. ${ }^{22}$ 음

In granting consent, parents will feel entitled to a $\frac{\bar{\rho}}{\vec{\rho}}$ quality necropsy ${ }^{2324}$ but what are the ethics of $\stackrel{\mathbb{Q}}{\Omega}$ seeking consent when this may not be fulfilled? It is likely that many parents would refuse consent and that clinicians would be less likely to request consent $\stackrel{\circ}{\circ}$ for necropsy if they were aware that the quality of $\vec{\omega}$ postmortem examination was less than adequate. ${ }^{25}$ o It is disturbing to note that as many as 44 per cent of perinatal necropsies may fail to reach an arbitrary minimum standard. ${ }^{24}$ In the United Kingdom, N there is no requirement for trainees to satisfy the ? Royal College of Pathologists of competence in perinatal pathology for accreditation in histopathology. Yet the majority of perinatal losses will occur in district general hospitals which will be staffed by $\rightarrow$ general histopathologists. Parenthetically, as long as academic promotion prospects and private practice opportunities are more attractive in general histopathology, perinatal pathology will always be seen as a Cinderella of histopathology with a resultant dearth of perinatal pathologists, as observed by Baird. $^{26}$

\section{What constitutes a necropsy in the perinatal period?}

In defining a necropsy, whether it is full or limited to organs of interest, it is often assumed that an incision is required to allow direct visualisation of visceral organs. The Australia Law Reform Commission describes a necropsy merely as a "postmortem examination of the body of the deceased for the purposes of scientific interest in determining the cause of death and other information that may be obtained that might aid medical science." 27 With many of the dysmorphic perinatal losses, an external examination of the body to include mensuration, photography and postmortem imaging, and ancillary $N$ testing of placental tissue for infections and for biochemistry and for cytogenetics, may provide a cause of death. ${ }^{1428} 29$ Molecular biology techniques are proving to be powerful tools in retrospective genetic testing or diagnosis of infection. Would these investigations constitute a necropsy? The definition of a postmortem examination limited to external viewing, photography and organ imaging may not find favour readily with pathologists but such careful assessments after death may yet prove abhorrent, albeit rarely, to some parents. Non-invasive investigations in lieu of a necropsy may respect the wishes of the parents ${ }^{30}$ but they are potentially problematic. Quite apart from the problems of definition of a necropsy, what are the implications of a significant pathological finding from these tests when necropsy 
consent had been refused? Since the findings may have been unsought by the parents, should the attending clinicians or parents be informed or not?

\section{Consent for use of tissue for research}

It is not the purpose of this paper to discuss issues relating to consent for use of fetal tissue for research. The Polkinghorne report recommends that specific informed consent be sought from parents for such use of tissue. ${ }^{15}$ This, in my opinion, is liable to subject the parents to further potential distress. It is possible that, having given consent to a necropsy, the parents could be confronted by five different sets of researchers asking for different tissues or parts of the same tissue obtained at necropsy for the purposes of research. It is a thankless task of research and ethics committees to balance parental rights and respect without stifling research, especially where the particular disease is rare. In our institution, we have a codicil to the necropsy consent form, which parents could revoke if they so wished, allowing fetal tissue to be taken for research. The research projects are vetted by the local research and ethics committee, which acts as a repository for the projects.

\section{Conclusions}

The mixed and often confusing emotions at the time of a perinatal loss cannot be underestimated and, as a caring profession, we should endeavour at least to be clear about the ethical and legal issues relating to the necropsy consent. The extent of the problems is not insignificant: it is estimated that there are 426,000 miscarriages, ${ }^{31}$ and 1,800 terminations performed under clause IV of the Abortion Act, 1967, for proven or suspected fetal abnormality ${ }^{32}$ and 5,700 stillbirths and neonatal deaths ${ }^{33}$ annually in England and Wales. The issues may not be readily resolved but public debate and ad hominem decisions on each perinatal loss may help to alleviate the problems.

T Y Khong, MD, MSc, MRCPath, is presently a Consultant Pathologist at the Adelaide Women's and Children's Hospital and Clinical Senior Lecturer in Pathology and in Obstetrics and Gynaecology in the University of Adelaide. He has specialised in perinatal pathology since 1983, having worked at St George's Hospital Medical School, London and fohn Radcliffe Hospital, Oxford.

\section{References}

1 Porter HJ, Keeling JW. Value of perinatal necropsy examination. Fournal of Clinical Pathology 1987; 40: 180-4.

2 Cartlidge PHT, Dawson AT, Stewart JH, Vujanic GM. Value and quality of perinatal and infant postmortem examinations: cohort analysis of 400 consecutive deaths. British Medical fournal 1995; 310: 155-8.
3 Saller DN, Lesser KB, Harrel U, Rogers BB, Oyer CE. The clinical utility of the perinatal autopsy. Fournal of the American Medical Association 1995; 273: 663-5.

4 Joint Working Party of the Royal College of Pathologists, Royal College of Physicians of London and Royal College of Surgeons of England. The autopsy and audit. London: The Royal College of Pathologists, 1991.

5 Smallwood R. The dead do tell tales. Medical Fournal of Australia 1994; 160: 389-90.

6 Editorial [anonymous]. Research after death. Lancet 1994; 344: 1517-8.

7 Standing Joint Committee of the British Paediatric Association and the Royal College of Obstetricians and Gynaecologists. Commentary on current World Health Organisation definitions used in perinatal statistics. British foumal of Obstetrics and Gynaecology 1986; 93: 1236-8.

8 South Australian Health Commission. Eighth report of the matemal, perinatal and infant mortality committee on matemal, perinatal and post-neonatal deaths in 1993. Adelaide: South Australian Health Commission, 1994.

9 Kamimura K. Epidemiology of twin births from a climatic point of view. British foumal of Preventative and Social Medicine 1976; 30: 175-9.

10 Editorial [anonymous]. Perinatal mortality rates - time for change? Lancet 1991; 337: 331.

11 Svendsen E, Hill RB. Autopsy legislation and practice in various countries. Archices of Pathology and Laboratory Mcdicinc 1987; 111: 846-50.

12 Editorial [anonymous]. When is a fetus a dead baby? Lancet 1991; 337: 526.

13 Khong TY, Hill F, Chambers HM, Staples A, Harry C. Acceptance of mementos of fetal and perinatal loss in a South Australian population. Australia and New Zealand foumal of Obstetrics and Gynaecology 1993; 33: 392-4.

14 Wigglesworth JS. Investigation of perinatal death. Archives of Disease in Childhood 1987; 62: 1207-8.

15 Polkinghorne J, Hoffenberg R, Kennedy I, Macintyre $\mathrm{S}$. Review of the guidance on the research use of fetuses and fetal material. London: Her Majesty's Stationery Office, 1987: 7 .

16 Jones E, Kay MA. The cultural anthropology of the placenta. In: Lavery JP, ed. The human placenta. Rockvilie: Aspen Publishers, 1987: 11-23.

17 Chana J, Rhys-Maitland R, Hon P, Scott P, Thomas C, Hopkins A. Who asks permission for an autopsy? foumal of the Royal College of Physicians of London 1990; 24: 185-8.

18 Khong TY. A review of perinatal autopsy rates worldwide 1960 s to 1990 s. Paediatric and Perinatal Epidemiology' (in press).

19 Chiswick M. Perinatal and infant postmortem examination. Difficult to ask but potentially valuable. British Medical foumal 1995; 310: 141-2.

20 Hunter AGW. Brain and spinal cord: disorders of neural tube closure. In: Stevenson RE, Hall JG, Goodman RM, eds. Human malformations and related anomalies vol II. New York: Oxford University Press, 1993: 109-37.

21 Valdes-Dapena M. The postautopsy conference with families. Archives of Pathology and Laboratory Medicine 1984; 108: 497-8.

22 Knowles S. A passage through grief - the Western Australian rural pregnancy loss team. British Medical fournal 1994; 309: 1705-8. 
23 Wigglesworth JS. Quality of the perinatal autopsy. British Foumal of Obstetrics and Gynaecology 1991; 98: 617-9.

24 Rushton DI. West Midlands perinatal mortality survey, 1987. An audit of 300 perinatal autopsies. British foumal of Obstetrics and Gynaecology 1991; 98: 624-7.

25 Waldron G. Perinatal and infant postmortem examination. Quality of examinations must improve. British Medical foumal 1995; 310: 870.

26 Discussants. The contribution of pathology to perinatal audit. In: Chalnıers I, McIlwaine G, eds. Perinatal audit and surveillance: Proceedings of the Eighth Study Group of the Royal College of Obstetricians and Gynaecologists, 1980. London: The Royal College of Obstetricians and Gynaecologists, 1980: 239-44.

27 The Royal College of Pathologists of Australasia. Autopsy and the use of tissues removed at autopsy. Medical Fournal of Australia 1994; 160: 442-4.

28 Sharma AK, Phadke SR, Kamboj M, Agarwal SS. The clinical value of a 'limited fetal autopsy' as illustrated by two cases. Australia and New Zealand Fournal of Obstetrics and Gynaecology 1994; 34: 111-3.

29 Bankier A. Approach to the dysmorphic child. Fournal of Paediatrics and Child Health 1990; 26: 69-70.

30 Raffles A, Ropel C. Perinatal and infant postmortem examination. Non-invasive investigations are also helpful if permission for a necropsy is refused. British Medical foumal 1995; 310: 870.

31 Morris D. Disposal arrangements for second trimester fetuses. British fournal of Obstetrics and Gynaecology on 1988; 95: 545-6.

32 MacKenzie IZ. Pregnancy termination. In: Brock DJH, Rodeck CH, Ferguson-Smith MA, eds. Prenatal diagnosis and screening. Edinburgh: Churchill Livingstone, 1992: 675-87.

33 Mortality statistics, childhood, England and Wales, 1992. London: Office of Population Censuses and Surveys, N 1994: 4-5.

\section{News and notes}

\section{International Association of Bioethics}

The III World Congress of the International Association of Bioethics will be held from November 22-24, 1996, at the Parc 55 Hotel in San Francisco. The conference will be preceeded on November $20-21$ by several other meetings, including an international bioethics summit of national ethics commission members, the annual meeting of the American Association of Bioethics, and a symposium on feminist bioethics. It will be followed on November 25 by a post-congress meeting, co-sponsored by the Human Genome Organization (HUGO) on the human genome diversity project and the patenting of human genes. For further information contact the Congress Organiser, Professor Alex Capron, the Law Center, University of Southern California, University Park, Los Angeles CA 9008-0071. Fax: + 1213740 5502; email: acapron( $a$ law.usc.edu, or Kay Boyle, Centre for Human Bioethics, Monash University, Australia 3168. Fax: + 6139905 3279; email: kboyle $(a$ arts.cc.monash.edu.au 